\title{
Motility of bacteria in sediments
}

\author{
Tom Fenchel* \\ Marine Biological Laboratory, University of Copenhagen, Strandpromenaden 5, 3000 Helsingør, Denmark
}

\begin{abstract}
Motility and chemotactic responses to dissolved organic matter of bacteria living within different types of sediments were investigated down to $35 \mathrm{~cm}$ beneath the sediment surface. At least $20 \%$ of bacteria swim, although they often attach temporarily to solid surfaces, and they respond to point sources of organic matter. Altogether their motile behaviour and their relative densities are very similar to what has previously been found for planktonic bacteria. Bacterial motility in sand and silt is about half that of motility in moving water.
\end{abstract}

KEY WORDS: Bacterial motility $\cdot$ Marine sediments $\cdot$ Chemotaxis

Resale or republication not permitted without written consent of the publisher

\section{INTRODUCTION}

It has been known for centuries that many, if not most, bacteria are motile at least under particular environmental circumstances or during part of their life cycle. Motile bacteria always respond to one or more types of chemical stimuli (Fenchel 2002). Thus a large fraction of planktonic bacteria are motile and show chemotactic attraction to point sources of different low molecular-weight organics (Blackburn et al. 1998, Blackburn \& Fenchel 1999, Fenchel 2001, Grossart et al. 2001). Planktonic bacteria also tend to attach periodically to solid surfaces and may eventually attach permanently, creating a biofilm on suspended particles (Fenchel 2001, Kiørboe et al. 2003). Motility patterns and the mechanism of chemotaxis of organotrophic planktonic bacteria are consistent with the classical model for bacterial motile behaviour (sensu Berg 1993). Swimming paths can be described as a random walk: cells swim in short, almost straight paths (socalled runs) interspersed by tumbles, during which swimming briefly stops; the bacteria then initiate another run in a direction more or less random relative to the previous swimming direction. The duration of runs is typically 0.5 to $1 \mathrm{~s}$ in a homogeneous environment and swimming velocity is typically 50 to $100 \mu \mathrm{m}$ $\mathrm{s}^{-1}$. In an attractant gradient, runs are shorter (and tumbles more frequent) as cells move down the gradient (away from the source of the attractant) and longer as they move up the gradient; consequently, they move towards the source of an attractant through a so-called biased random walk. Tumbling is thus suppressed or induced as the cells experience increasing or decreasing attractant concentrations, respectively, over time. This type of motile behaviour was first described for enteric bacteria, but also applies to most free-living bacteria, such as planktonic bacteria, and is the most effective strategy for finding point sources of substrates (Blackburn \& Fenchel 1999).

With regards to sediments, most emphasis on motile behaviour has been on the chemosensory behaviour of bacteria with a preference for a given $\mathrm{O}_{2}$ tension in 1-dimensional oxygen gradients; most of the studied bacteria have been sulphide oxidisers. These organisms have evolved different mechanisms of swimming behaviour and chemotactic strategies in response to $\mathrm{O}_{2}$ tension. They orient themselves in essentially 1-dimensional diffusion gradients; in this case, reversal swimming when encountering adverse conditions is a more effective strategy than random re-orientation after tumbling. The involved organisms occur in the oxycline of sediments typically close to or at the sediment surface (see Barbara \& Mitchell 1996, Thar \& Fenchel 2005, and references therein). Little attention has so far been given to bacterial motility and chemotaxis in bulk sediments. Some attention has been given to movement of bacteria through sand, but these studies are concerned primarily with the risk of aquifer 
contamination with pathogens, rather than the adaptive significance of motility for indigenous microbial biota (e.g. Barton \& Ford 1997).

The present study estimates the fraction of motile bacteria in sediments with different mechanical properties and investigates whether they display chemosensory behaviour and to what extent bacteria are permanently attached to sediment particles. The surface layers of porous sediments may provide heterogeneous habitats due to advection of the interstitial water and in shallow habitats the daily light:dark cycle results in vertical migrations of the oxycline due to photosynthesis. At depths where bioturbation is active, the sediment will be spatially heterogeneous in terms of small aerobic patches and distribution of organic matter; as such, motility would appear adaptive. This is less obvious beneath the bioturbation zone because this is an environment that would be expected to be more homogeneous and very poor in degradable organic matter.

\section{MATERIALS AND METHODS}

Study sites and sampling. All samples were collected in the northern part of the Øresund Sound, inner Danish waters. Sediment cores from shallow water samples were collected by hand in the Helsingør North Harbour, in a sandy beach north of the harbour, and in the shallow Nivå Bay, at depths between 0.5 and $1 \mathrm{~m}$. The median grain size of the harbour sediment is $230 \mu \mathrm{m}$; the surface sediment is rich in cyanobacteria, diatoms, and other microalgae. The beach sand is clean and well sorted with a median grain size of $180 \mu \mathrm{m}$. Nivå Bay sediments have a median grain size of ca. $230 \mu \mathrm{m}$ and a varying amount of organic detritus. The porosity of all these sandy sediments is ca. $30 \%$. A series of samples were collected along a linear transect in Hornbæk Bay at water depths ranging from 10 to $28 \mathrm{~m}\left(56^{\circ} 05.352^{\prime} \mathrm{N}, 12^{\circ} 31.336^{\prime} \mathrm{E}\right.$ to $56^{\circ} 06.310^{\prime} \mathrm{N}, 12^{\circ} 32.920^{\prime} \mathrm{E}$ ) using a Kajak sediment core sampler (KC Denmark), which provided cores of up to $35 \mathrm{~cm}$ depth in the soft sediments and somewhat shorter ones in sandy sediments. The median grain size ranged from $120 \mu \mathrm{m}$ (with $14 \%$ silt) at the deepest locality to $230 \mu \mathrm{m}$ at the most shallow locality. The corer was also applied for collecting a number of samples north of the island Ven (ca. $55^{\circ} 56^{\prime} \mathrm{N}, 12^{\circ} 42^{\prime} \mathrm{E}$ ) at depths ranging between 28 and $35 \mathrm{~m}$. The sediment consists mainly of silt (median grain size of $60 \mu \mathrm{m}$ and with porosities ranging from $68 \%$ at the surface layers to $58 \%$ at a depth of $35 \mathrm{~cm}$ ) with a large fraction of clay particles. In the laboratory cores were sectioned vertically into 1,2 or $3 \mathrm{~cm}$ slices and processed immediately. Samples were taken at different seasons in the harbour and at the deep locality north of Ven, and more sporadically at the other localities from autumn 2005 to summer 2007.
Mechanical properties of sediments and sedimentation rates. Grain size distribution was estimated through dry sieving for sands and through wet sieving for fine-grained sediments using a set of sieves (Endecotts) with apertures ranging between 1000 and $35 \mu \mathrm{m}$. Total surface area and dimensions of the interstitia were estimated on the basis of confocal scanning microscopy on sediment samples to which the fluorochrome rhodamine was added; this showed the outline of sediment particles within a horizontal section in an undisturbed sample. Internal surface area was estimated by placing a straight line over photographs of these preparations. The number of intersections per unit length of the lines and the outlines of sediment particles then equals surface area per unit volume of sediment (Aherne \& Dunnill 1982). Sedimentation rate and depth of the bioturbation zone was estimated from a core taken north of Ven at the Gamma Dating Centre, Institute of Geography (University of Copenhagen) on the basis of $\mathrm{Pb}-210$ and $\mathrm{Cs}-137$ (the latter indicating the Chernobyl year 1987) and from the vertical porosity profile. The vertical distribution of animal burrows was studied on X-ray photographs of $2 \mathrm{~cm}$ slices $(65 \mathrm{kV}$, $2 \mathrm{~mA}, 3.5 \mathrm{~min}$ exposure, and $35 \mathrm{~cm}$ between samples and films). These photographs were made at Bevaringscenter Næstved, Næstved, Denmark.

Total number and motile behaviour of bacteria. Total numbers of bacteria in sandy sediments were estimated directly on formalin-fixed sediments stained with DAPI using fluorescence microscopy; this was based on counting numbers of bacteria per unit surface area of sediment particles and on the calculated total surface area per unit volume of sand. For silty and muddy sediments a known volume of sediment was fixed with $2 \%$ formaldehyde and stained with a few drops of DAPI $\left(1 \mu \mathrm{g} \mathrm{ml}^{-1}\right)$ and then diluted 1:500 with sterile, $0.2 \mu \mathrm{m}$ filtered water. While maintaining particles in suspension, $1 \mathrm{ml}$ of the suspension was withdrawn, diluted in sterile water, filtered onto Nuclepore filters (diameter $1 \mathrm{~cm}, 0.2 \mu \mathrm{m}$ ) and at least 200 cells were counted under the fluorescence microscope. Some samples were instead incubated live with Live/Dead stain (Bacterial Viability Kit, Molecular Probes). Estimates of total counts based on this stain did not differ significantly from counts based on DAPI staining.

Estimation of number of motile bacteria. The concentration of motile bacteria was estimated in 2 ways. One was based on the migration of bacteria into hypodermic needles. Needles $(20 \mathrm{~mm}$ long, with an external diameter $0.4 \mathrm{~mm}$ and an internal diameter of $0.25 \mathrm{~mm}$ ), were attached to $1 \mathrm{ml}$ syringes and filled with sterile, filtered seawater. The tips of the needles were beveled, giving their apertures an ellipsoid shape (length of the major axis: $0.6 \mathrm{~mm}$, area: $0.12 \mathrm{~mm}^{2}$ ). 


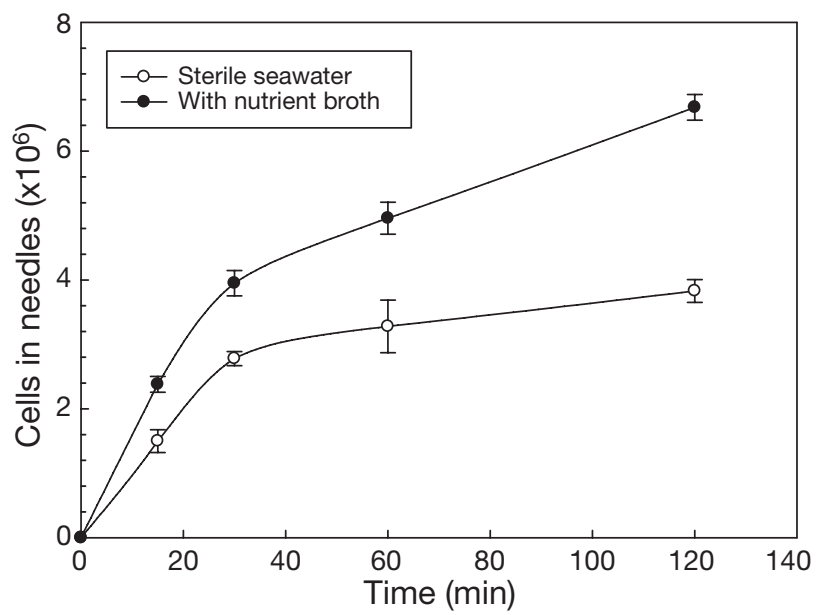

Fig. 1. Number of bacteria moving into hypodermic needles filled with sterile seawater and a nutrient broth solution, and inserted in sand from the beach site

Needles were pressed into the sediment at a slight angle with the aperture facing upwards, thus preventing sediment particles from entering. For each experiment 5 or 6 needles were simultaneously inserted in a given sediment sample. The syringes were then removed at different time intervals during the following 2 or $4 \mathrm{~h}$. Formaldehyde (ca. $0.5 \mathrm{ml}$ ) and a few drops of a DAPI solution were drawn into the syringe, followed by approximately $0.5 \mathrm{ml}$ sterile water, and the liquid was then pressed through a cartridge attached to the syringe holding a $1 \mathrm{~cm}, 0.2 \mu \mathrm{m}$ Nuclepore filter. The filters were then mounted on slides and counted under a fluorescence microscope. In these experiments the number of bacteria in the needles initially increased, but reached a steady state after 30 to $60 \mathrm{~min}$ (Fig. 1).

This provides 2 independent ways of estimating of the number of motile cells in the environment. In a suspension of motile microbes, the number of cells that pass a given area per unit time is given by $F=v \times C / 4$, where $v$ is swimming velocity and $C$ is the concentration of randomly swimming cells. The equation applies irrespective of particular swimming patterns, e.g. frequency of tumbling - the only (realistic) assumption is that swimming directions of the cells are random (Ojakian \& Katz 1973). Initially the syringe is free of bacteria, so in principle the initial flux of bacteria into the syringe during the first 5 to $15 \mathrm{~min}$ is a measure of the concentration of swimming bacteria surrounding the needle tip at any one moment. Mean swimming velocities were measured separately (see below). Since most swimming bacteria are attached to mineral grains some of the time (see below) the equation above will provide an underestimate of the number of motile bacteria that only swim periodically.
After more than $1 \mathrm{~h}$ it was assumed that cell concentrations inside and outside the syringe needles reflected the number of potentially motile bacteria in the surrounding sediment. This may have provided an underestimate because cells may not yet have reached an even distribution within the needle (in some cases a very slow increase in the number of cells was observed after $1 \mathrm{~h}$ ). Dividing absolute cell numbers by the internal needle volume as an estimate of cell concentration may then have yielded a too-low estimate of the ambient concentration of motile cells. Furthermore, the steady-state concentration may have been affected by the amount of available surface area compared to a similar volume of sediment; other factors, such as needle material (stainless steel) also may have rendered the needles more or less attractive to the bacteria. The surrounding sediment was in most cases anoxic, while the water in the syringe needles initially contained water with atmospheric $\mathrm{O}_{2}$ tension. Experiments that compared needles filled with anoxic and with aerated water did not, however, show any significant differences (data not shown). In glass capillaries (see below) left for many hours, some bacteria formed a band close to the meniscus, indicating that many bacteria in the anaerobic sediments were facultative aerobes.

In all cases, there was a linear relation between the 2 ways of estimating the concentration of swimming cells (Fig. 2). The method was also tested by adding a suspension of a cultured isolate of a motile marine bacterium to autoclaved sand (Fig. 3); this showed that the needle method at least provided an approximation to the true number of swimming cells.

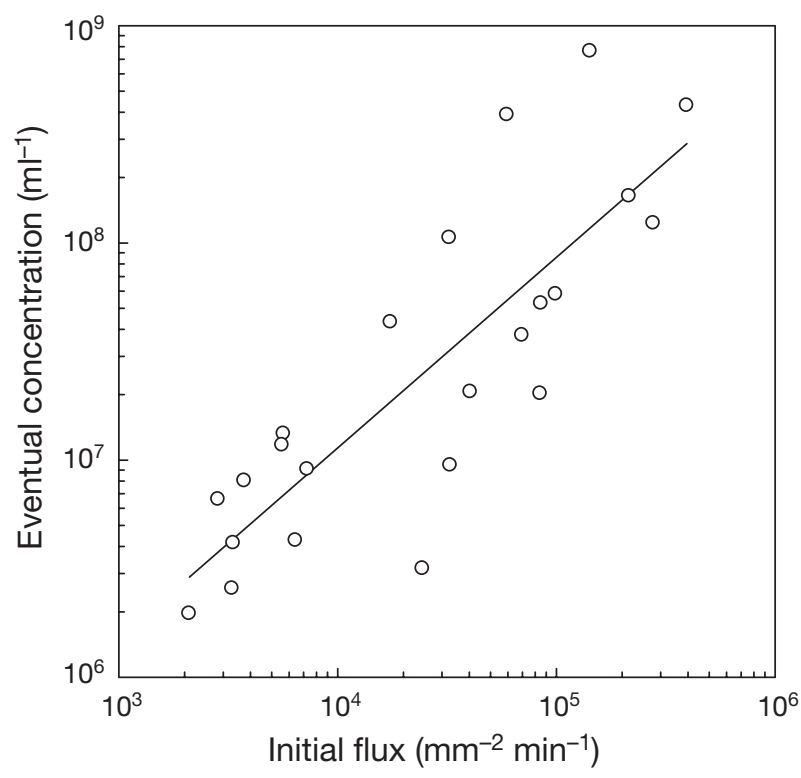

Fig. 2. Initial flux of bacteria into hypodermic needles with sterile water and eventual concentration of cells (after 2 to $3 \mathrm{~h}$ ) for all sandy sites studied 


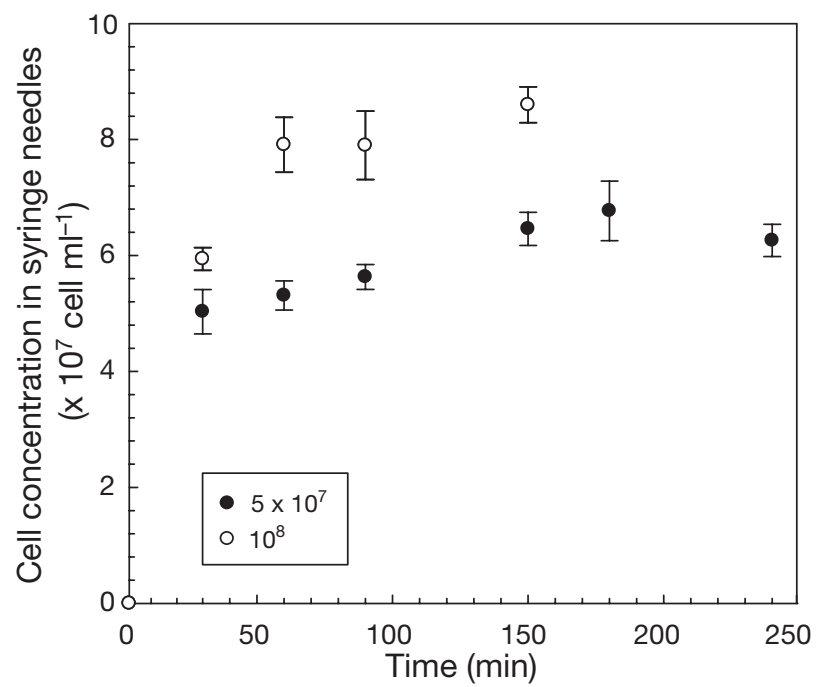

Fig. 3. Cell concentrations of a cultured bacterium in hypodermic needles with sterile seawater of 2 porewater concentrations that had been mixed into sterile sand from the beach site at concentrations of $5 \times 10^{7}$ and $10^{8} \mathrm{ml}^{-1}$ porewater

An alternative method was to use $8 \mathrm{~mm}$ wide by $0.8 \mathrm{~mm}$ deep flat glass capillaries (VitroCom) instead of hypodermic needles. These capillaries were filled with sterile seawater and a known volume (ca. $30 \mu \mathrm{l}$ ) of sediment was then pushed into one end; both ends were then capped with Vaseline. The number of bacteria that migrated out of the sand over time could then be observed and counted directly with phase contrast microscopy. In so far as some bacteria may be attracted to and stay within the sediment, rather than migrating out into the water, this method is also likely to provide underestimates of the number of swimming bacteria, but the results were consistent with those obtained by the needle approach. Video recordings of these preparations also served to estimate swimming velocities, frequency of tumbling, and frequency of attaching.

In order to estimate chemosensory responses, experiments similar to those described above were carried out, but the sterile seawater was exchanged with a sterile $2 \%$ solution of nutrient broth (Oxoid) in seawater. The initial rate of bacterial flux increased relative to sterile seawater and no steady state was reached; rather, after about $0.5 \mathrm{~h}$ there was a linear increase in bacteria over time (see Figs. 1 \& 8). This must reflect that the migration to the point source from which organic matter diffuses into the environment (the needle aperture) is transport ('diffusion') limited. This provides a method for estimating the motility ('diffusion coefficient') of bacteria in water and in different types of sediment, based on the equation $I=4 \operatorname{DrC}$, which describes the diffusive current $(I)$ to an absorbing disk (the syringe needle aperture), where $D$ is the 'diffusion coefficient' (i.e. bacterial motility), $r$ is the radius of the needle aperture (here considered as the geometric mean of the major and minor semi-axes of the aperture), and $C$ is the concentration of bacteria at an infinite distance (Berg 1993). For these experiments a motile bacterium isolated from seawater and grown on nutrient broth was mixed homogeneously into sterilised sediments in order to have a precise a priori estimate of the concentration of bacteria. The (unnamed) bacterium has swimming properties (swimming velocity, tumble frequency) also typical of the majority of cells encountered in the sediments.

\section{RESULTS}

\section{Number of motile cells}

The number of motile bacteria showed a great variation in the shallow sampling localities, ranging from $<10^{7}$ to $>5 \times 10^{8} \mathrm{ml}^{-1}$ in the sediment at the North Harbour and the beach site, and between $1.8 \times 10^{7}$ and $4 \times$ $10^{8} \mathrm{ml}^{-1}$ at the Nivå Bay locality. The numbers correlated with season and the highest values derived from late summer. These numbers typically constituted 10 to $20 \%$ of total counts. At the deeper localities the total numbers and fraction of motile cells were more stable throughout the year. At the deepest Hornbæk Bay locality the surface sediments harboured 3 to $5 \times 10^{7}$ motile cells $\mathrm{ml}^{-1}$, a value that decreased about an order of magnitude below a depth of $11 \mathrm{~cm}$. This corresponded to $10 \%$ motile cells at the surface and 2 to $4 \%$ at a depth of $11 \mathrm{~cm}$. In the silty sediment north of Ven, total counts, as well as numbers of motile cells, remained rather constant throughout the year ( 1 to $2 \times$ $10^{8}$ and 3 to $4 \times 10^{7} \mathrm{ml}^{-1}$, respectively) so that at least $20 \%$ of the cells (total counts) are motile at all depths (Fig. 4). It is known that DAPI also stains metabolically inactive cells or cells with damaged membranes. Dead/live staining indicated that the fraction of metabolically active cells constituted ca. $70 \%$ (on one occasion $72 \%$; SD of the mean: $9 \%$ ) averaged over all depths from the surface to $22 \mathrm{~cm}$, suggesting that swimming cells constitute a correspondingly larger fraction of metabolically active cells. Samples were not collected immediately after the spring bloom at this locality; it is likely that the surface layers of the sediment would then have contained much higher concentrations of bacteria.

\section{Spatial heterogeneity}

Surface layers of sediments constitute considerable spatial heterogeneity due to things like animal burrows and discrete detrital particles (Fenchel 1996, 


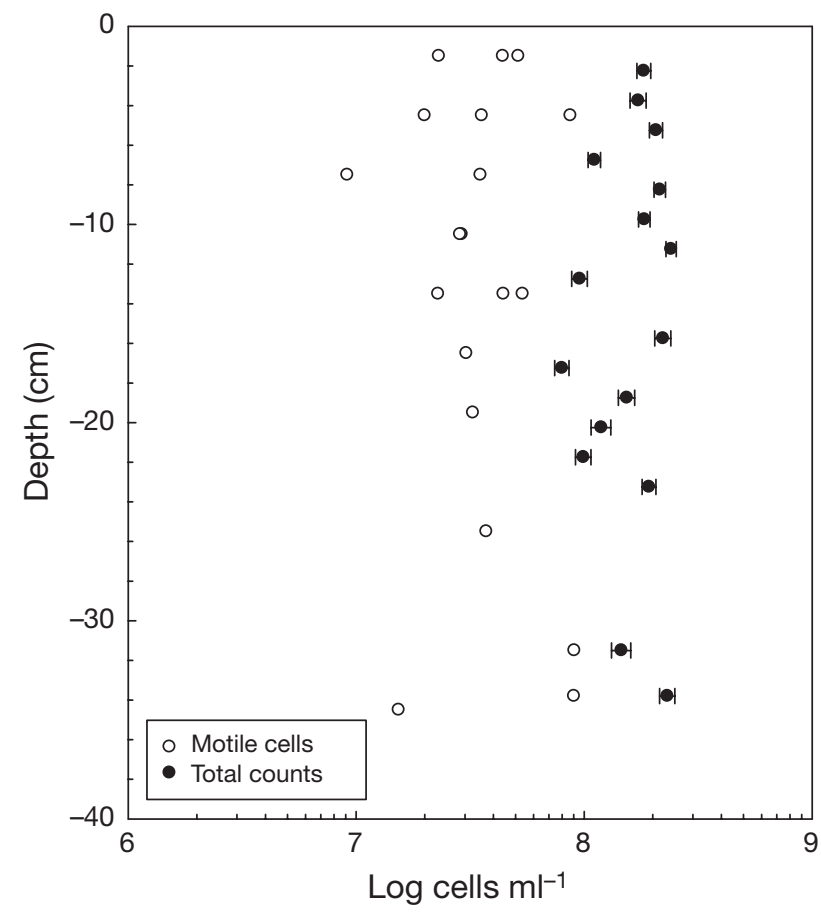

Fig. 4. Total counts (DAPI) and concentration of motile bacteria in either hypodermic needles or flat capillaries at the site north of the island Ven. Samples were collected in August and November 2006 and May 2007

Rosenberg \& Ringdahl 2005). This is reflected in the variation of the number of swimming cells along a horizontal $6 \mathrm{~cm}$ transect of surface sediments from the harbour (Fig. 5).

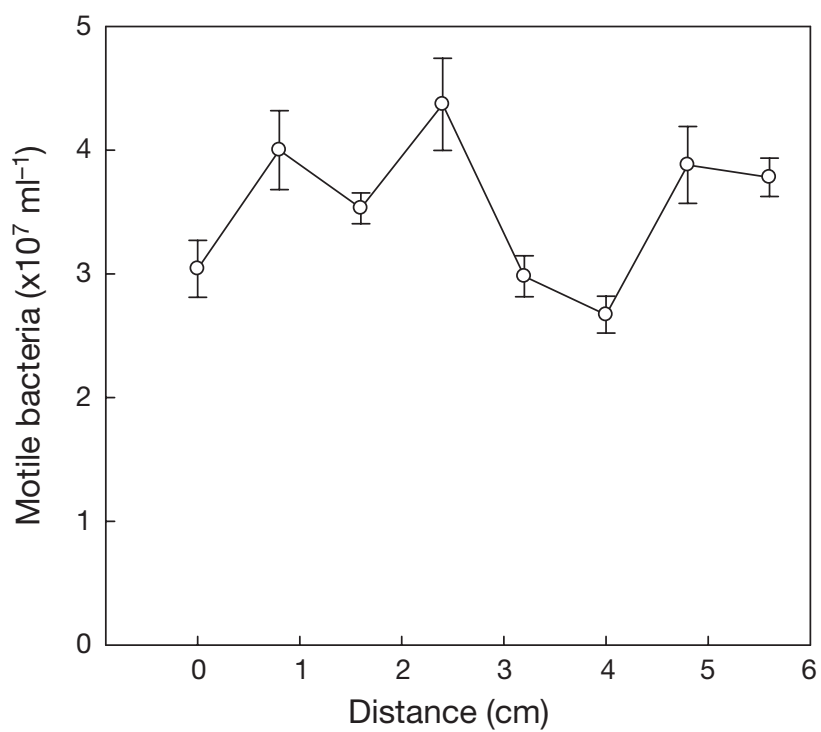

Fig. 5. Motile bacteria along a horizontal linear transect in the surface sand of an undisturbed sample from the North Harbour as estimated from the eventual bacteria concentrations in 8 hypodermic needles inserted in a line
In the silt at the deep locality north of Ven, X-ray photographs showed that the upper $10 \mathrm{~cm}$ of the sediment contained many biogenic structures, in particular invertebrate burrows (mainly polychaetes, molluscs, and crustaceans), although it is not clear how many of these were inhabited and how many represented uninhabited 'fossil' burrows (Fig. 6). The Pb-210 profile indicated active bioturbation down to ca. $15 \mathrm{~cm}$ depth, beneath which $\mathrm{Pb}-210$ concentration decreased exponentially. The deepest part of the core $(35 \mathrm{~cm})$ was deposited in ca. 1950 so that they have been undisturbed for decades presumably with no or very slight addition of easily degradable organic matter. Nevertheless, this apparently did not affect total bacterial numbers or numbers of swimming cells.

The surface layer of shallow sediments showed considerable patchy distribution of bacterial cells on sand grains and the presence of many micro-colonies. Patchy distribution of bacteria occurred in the deep silty samples around burrows, but was otherwise random and practically without microcolonies.

\section{Chemotaxis}

The initial flux of bacteria into needles was typically 2 to 3 times higher into needles containing nutrient broth compared to control needles with seawater alone when needles with and without nutrient broth were inserted simultaneously into a sediment sample (Figs. 1 \& 7). Also, after about $30 \mathrm{~min}$, a linear increase in bacteria was sustained for at least $4 \mathrm{~h}$ after insertion of the needles, showing that a large fraction of bacteria in all types of sediments and at different depths are adapted to approach point sources of readily degradable organic matter.

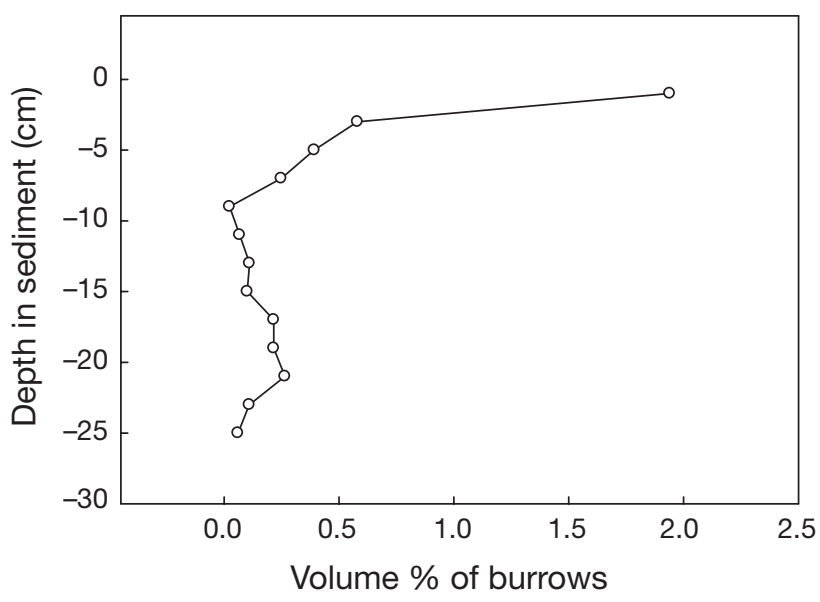

Fig. 6. Average volume fraction of animal burrows from the site north of Ven calculated from X-ray photographs of four $2 \mathrm{~cm}$ sediment slices 


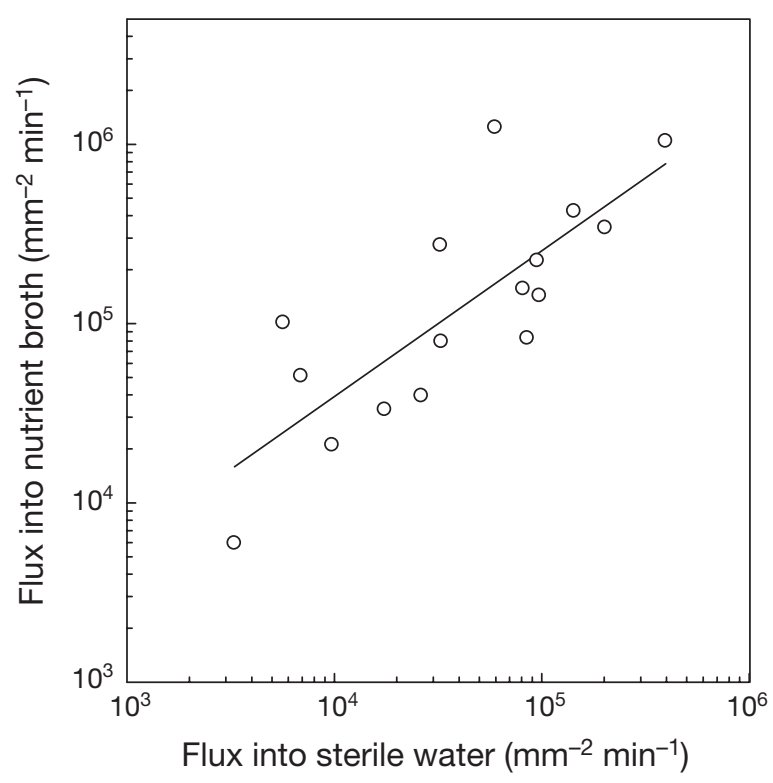

Fig. 7. Initial flux ( 0 to 5,10 , or $15 \mathrm{~min}$ ) of bacteria into pairs of hypodermic needles with and without nutrient broth in different types of sediments

\section{Motile behaviour}

Swimming bacteria that left the sediment showed a motile behaviour that was comparable to that of previously studied organotrophic bacteria (see Berg 1983, Blackburn \& Fenchel 1999) with runs interspersed by tumbles. Different morphotypes of cells showed a limited variation in parameter values. On average, cells that had left the silty sediment from north of Ven swam with a velocity of $v=63.5 \pm 15 \mu \mathrm{m} \mathrm{s}^{-1}$ (mean \pm SD) and a time interval between tumbles of $\tau=0.86 \pm 0.52 \mathrm{~s}$. Motility ('diffusivity') is given by $v^{2} \tau / 3$, assuming random reorientation in swimming direction following tumbles (Berg 1983). The time for a tumble is $<40 \mathrm{~ms}$ and can essentially be ignored in this context. A bacterium swimming with above-mentioned average parameter values will then have a motility of $1.2 \times$ $10^{-5} \mathrm{~cm}^{-2} \mathrm{~s}^{-1}$.

The time spent with temporary attachment to the walls of the capillary varied. In 2 samples from the silty sediment the percentage of swimming cells at any one time were 70.9 and 39.3, respectively; there were no systematic differences at different depths in the sediment. Similar values were found for sandy sediments (North Harbour and Nivå Bay). However, in another sample from the deeper, silty sediment the fraction of swimming cells was $<10 \%$ at any one moment. The mean fraction of time spent attached in the latter case ranged between about 6.6 and $31.6 \mathrm{~min}$. Bacteria extracted from sand spent on average 20 to 25 min attached to the glass walls before swimming on. These values are not necessarily representative of the behaviour within sediments, but could be affected by chemical cues and the proximity of solid surfaces.

Cell motility is likely to be lower in sediments than in water partly due to tortuosity, i.e. the path length is increased due to the necessity of swimming around solid particles, the increased probability of attaching to surfaces, and the slowing of bacterial swimming close to solid surfaces due to viscous forces (Frymier \& Ford 1997). By applying the constant flux of bacteria into needles with an attractant, it was possible to calculate the motility in water, sand and silt (Fig. 8), showing that motility in sand is about half that of motility in water; in silt motility appears to be further reduced. Motility in water estimated this way was higher than that estimated from swimming velocities and tumbling frequencies (ca. $1.2 \times 10^{-5} \mathrm{~cm}^{2} \mathrm{~s}^{-1}$ ). The reason is per-
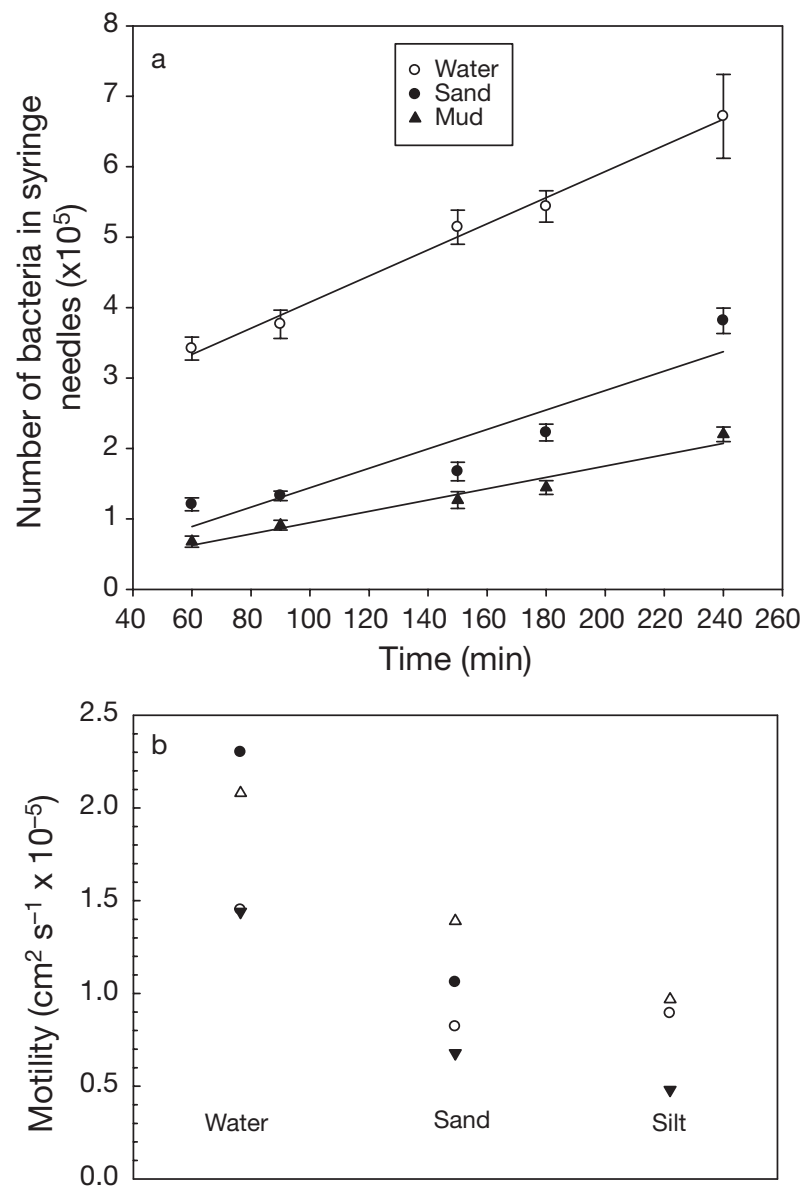

Fig. 8. (a) Linear migration of bacteria into hypodermic needles containing a nutrient broth solution and inserted into seawater, sand or silt with a cultured bacterium. Data have not been corrected for somewhat different cell concentrations in the 3 types of sediment (because the bacterial suspension was diluted by remaining sterile pore water when mixed into the sediment). (b) Calculated motility in water, sand, and silt based on 4 such sets of experiments (indicated by different symbols) 
haps that in the needle experiments, the area of the 'absorbing disk' is somewhat larger then the aperture of the needles because the nutrient broth will slowly diffuse into the surrounding water. However, the relative motilities in water and in the 2 different types of sediment may still hold.

\section{DISCUSSION}

Microbial motility in sediments can only be observed indirectly and the present survey presents only a rough estimate of the number of swimming cells. Furthermore, precise estimates of total numbers of cells in sediment are difficult to obtain. However, the results do show that a substantial number (ca. 20\%) swim and that organotrophs are adapted to approach point sources of degradable organic matter. This is clearly adaptive in the upper part of the sediment, where bioturbation distributes organic detrital particles down to depths of ca. $\geq 10$ to $15 \mathrm{~cm}$ (Josefson et al. 2002, Rosenberg et al. 2007 and author's data on Pb-210 distribution). The surroundings of inhabited burrows provide special environments that may provide particular habitat patches for certain physiological types of bacteria (Fenchel 1996, Papaspyrou et al. 2006). It is less obvious how bacteria beneath the zone of bioturbation can utilise chemosensory behaviour and indeed how population densities similar to those found closer to the sediment surface are maintained.

In terms of both the fraction of swimming cells and of swimming behaviour, bacterial motility seems quite similar to what has been found for planktonic bacteria (Blackburn \& Fenchel 1999, Fenchel 2001). Motility, however, is reduced in sediments when compared to free water. This seems mainly to be caused by the proximity of surfaces that slow down swimming velocity (Frymier \& Ford 1997) and stimulate temporary attachment. Tortuosity plays a relatively small role. This is because motility apparently was negatively correlated with porosity, while tortuosity is positively correlated with porosity (Ullman \& Aller 1982). The porosity of the silty sediment was $>60 \%$, whereas in sandy sediments it is only ca. $30 \%$; however, the finer sediment caused a larger reduction in motility than did sand. Perhaps this is related to the fact that the permeability of fine sediments is lower than in coarser sediments, which must also be a question of internal surfaces.

There is evidence of bacterial activity in sediments beneath the zone of bioturbation. At the site north of Ven, Glud \& Middelboe (2004) showed that viral infection causes a turnover of the bacterial population in ca. $4 \mathrm{~d}$ at a depth of $10 \mathrm{~cm}$ in the sediment and they also demonstrated the generation of inorganic carbon. At this site I have also observed the presence of bacterivorous protozoa (flagellates, amoebae) at depths down to $35 \mathrm{~cm}$, although they have not been adequately quantified (author's unpubl. data). Grossart et al. (2001) directly suggested that motile bacteria may serve as a measure of metabolically active cells in so far as if a bacterium swims it must be alive. Bacteria have now been found hundreds of metres beneath the surface of deep-sea sediments, although these organisms must subsist at extremely low metabolic rates (Jørgensen \& Boetius 2007). It will be interesting to see whether motility is also a characteristic of such biota.

Acknowledgements. I am grateful to Dr R. Thar for help using confocal scanning microscopy and for technical assistance from M. Saitz. I am also grateful to Dr T. J. Andersen (Gamma Dating Centre, University of Copenhagen) for the radiometric analysis and to Bevaringscenter Næstved for assistance in making X-ray photos of sediment samples. Support was received from the Carlsberg Foundation and from the Danish Natural Science Research Council.

\section{LITERATURE CITED}

Aherne WA, Dunnill MS (1982) Morphometry. Edward Arnold, London

Barbara GM, Mitchell JG (1996) Formation of 30-40 micrometer thick laminations by high speed marine bacteria in microbial mats. Appl Environ Microbiol 62:3985-3990

Barton JW, Ford RM (1997) Mathematical model for characterization of bacterial migration through sand cores. Biotechnol Bioeng 53:487-496

Berg HC (1983) Random walks in biology. Princeton University Press, Princeton, NJ

Blackburn N, Fenchel T (1999) Influence of bacteria, diffusion and shear on micro-scale nutrient patches, and implications for bacterial chemotaxis. Mar Ecol Prog Ser 189:1-7

Blackburn N, Fenchel T, Mitchell J (1998) Microscale nutrient patches in planktonic habitats shown by chemotactic bacteria. Science 282:2254-2256

Fenchel $\mathrm{T}$ (1996) Worm burrows and oxic microniches in sediments. 1. Spatial and temporal scales. Mar Biol 127: 289-295

Fenchel T (2001) Eppur si muove: many water column bacteria are motile. Aquat Microb Ecol 24:197-201

> Fenchel T (2002) Microbial behaviour in a heterogeneous world. Science 296:1068-1071

Frymier PD, Ford RM (1997) Analysis of bacterial swimming speed approaching a solid liquid interface. AIChE J 43: 1341-1347

Glud RN, Middelboe M (2004) Virus and bacteria dynamics of a coastal sediment: implications for benthic carbon cycling. Limnol Oceanogr 49:2073-2081

Grossart HP, Riemann L, Azam F (2001) Bacterial motility in the sea and its ecological implications. Aquat Microb Ecol 25:247-258

Jørgensen BB, Boetius A (2007) Feast and famine - microbial life in the deep sea. Nature Rev Microbiol 5:770-781

Josefson AB, Forbes T, Rosenberg R (2002) Fate of phytodetritus in marine sediments: functional importance of macrofaunal community. Mar Ecol Prog Ser 230:71-85 
Kiørboe T, Tang K, Grossart HP, Ploug H (2003) Dynamics of microbial communities on marine snow aggregates: colonization, growth, detachment, and gazing mortality. Appl Environ Microbiol 69:3036-3047

Ojakian GK, Katz DF (1973) A simple technique for the measurement of swimming speed of Chlamydomonas. Exp Cell Res 81:487-491

Papaspyrou S, Gregersen S, Kristensen E, Christiansen B, Cox RP (2006) Microbial reaction rates and bacterial communities in sediment surrounding burrows of two nereid polychaetes (Nereis diversicolor and N. virens). Mar Biol 148:541-550

Rosenberg R, Ringdahl K (2005) Quantification of biogenic

Editorial responsibility: Antje Boetius,

Bremen, Germany
3-D structures in marine sediments. J Exp Mar Biol Ecol 326:67-76

Rosenberg R, Davey E, Gunnarsson J, Norling K, Frank M (2007) Application of computer-aided tomography to visualize and quantify biogenic structures in marine sediments. Mar Ecol Prog Ser 331:23-34

Thar R, Fenchel T (2005) Survey of motile microaerophilic bacterial morphotypes in the oxygen gradient above a marine sulfidic sediment. Appl Environ Microbiol 71: 3682-3691

Ullman WJ, Aller RC (1982) Diffusion coefficients in nearshore marine sediments. Limnol Oceanogr 27: $552-556$

Submitted: October 4, 2007; Accepted: February 13, 2008

Proofs received from author(s): April 7, 2008 